\title{
KONTEKS ILMU PENDIDIKAN ANTROPOLOGI DALAM PERSPEKTIF KOMUNIKASI
}

\author{
Resty Nurqomah \\ 2010128220014@mhs.ulm.ac.id \\ Program Studi Pendidikan IPS Fakultas Keguruan dan Ilmu Pendidikan \\ Universitas Lambung Mangkurat
}

\begin{abstract}
Abstrak
Dalam kehidupan pendidikan pembelajaran di Indonesia sekarang, menempati situasi yang harusnya secara baik dapat membuat individu manusia diberi bekal ilmu pengetahuan secara substansif ataupun praktis yang pasti digunakan. Fakta yang ada justru kebalikannya, di mana menjadi hambatan pada pertumbuhan seterusnya. Hal ini terbentuk tujuan dalam memberi sesuatu mengenai konteks ilmu pendidikan antropologi dalam perspektif komunikasi yang diharuskan juga mengupayakan membuat nasonalis di Indonesia menjadi sesuatu hal yang terbaru, yang nantinya akan dapat mengatasi permasalahan kritis percampuran susunan komunikasi secara globalisasi. Pendidikan antropologi dalam perspektif komunikasi merupakan cara lihat komunikasi dari sisi antropologi, sebab adanya komunikasi itu memuat hasil suatu nilai. Salah satunya terjadi komunikasi antar sosial juga budaya, di mana hal ini diambil dari pernikahan antar disiplin ilmu antropologi dan pada komunikasi, yang selanjutnya akan jadi disiplin yang sendiri, baik itu pada antropologi ataupun pada ilmu komunikasi.
\end{abstract}

Kata Kunci: Ilmu Antropologi, Pendidikan, Komunikasi

\section{Pendahuluan}

Pendidikan bisa di dapatkan dari keluarga, sebab tertanam hasil budaya, seperti aturan, cara pandang, berperilaku pada kehidupannya, juga ahli bersosial (Abbas, 2001, 2018a, 2018b; Abbas, 2018; Hardian, 2006). Pada ilmu antropologi dengan keseluruhan pastinya harus diberikan peluang untuk menumbuhkan cara berapresiasi, afektif secara memiliki empati, juga bersifat kognitif. Di mana hal ini karena di dapat dari pengalaman berkehidupan, secara dari 
subjek yang di dapat dari belajar. Dasar kebaikan serta moral dilakukan secara diawasi juga dibimbing (Mutiani, 2009; Subiyakto, 2020; Subiyakto \& Mutiani, 2020). Untuk mengembangkan hal ini, seperti mendekati pada reflektif partisipasi sehingga bisa mengambil sifat kognitif juga simbol tanda sosial-budaya yang akan pastinya berubah-ubah. Hingga mendapat nilai yang bersifat ilmu pengetahuan apresiatif serta reflektif. Yakni pada temuan eksistensi individu itu sendirinya. Ilmu antropologi adalah salah satu cabang dari bidang keilmuan, jadi landasan melahirkan ilmu komunikasi. Sangat penting komunikasi, seperti di bidang kebudayaan. Dengan definisi ini dituturkan pada "Intercultural Communication, A Reader" menyebutkan pada komunikasi pada definisi kebudayaan (Intercultural Communication) akan terjadi, ketika message itu dipahami juga di dapat dari member suatu kebudayaan.

Sehingga dapat diterima member suatu kebudayaan lainnya (Samovar \& Porter, 1994: 19) serta (Linton, 1945, 32) menuturkan kebudayaan ialah tingkah laku individu pada elemen transformasi dari member warga. Kebanyakan kebudayaan dianggapkan selaku punya individu yang dipergunakan pada alat untuk komunikasi secara sosial dengan di dalam adanya proses peniruan. Ilmu antropologi disebutkan selaku landasan akan kelahiran adanya ilmu komunikasi. Yang sesuai pertumbuhan antropologi ini, membuat ahli kebudayaan melihat adanya kebudayaan sangatlah bergantung pada yang namanya komunikasi. Sehingga dilakukan kajian tentang adanya komunikasi ini, yang akhirnya melahirkan ilmu komunikasi, karena ilmu antropologi. Tetapi secara jelas tentang hubungan keduanya, harus dilihat dari sisi antropologi juga pada komunikasi sendirinya. Ilmu antropologi mengatasi permasalahan yang terjadi di hadapan peserta didik, seperti pada mengatasi perut, mengatasi karir kedepannya, juga mengatasi masa yang akan datang serta sebagainya. Berhubungan hal ini, apa yang dapat dilakukan dari keahlian pada bidang ilmu antropologi untuk mengatasi perut, karir, serta masa yang akan datang secara baik untuk dirinya itu, yang nanti setelah kelulusannya (Shahab, 2006).

\section{Ilmu Pendidikan Antropologi Di Indonesia}

Pelaksanaan pembelajaran akan mendapat hasil adanya berubah tingkah laku (Abbas, 2017; Putro, 2020; Subiyakto \& Mutiani, 2020). Letak ilmu antropologi di wilayah Indonesia akan memberi tanggapan pada kehidupan dulu serta kehidupan sekarang maupun percampuran yang dirasakan warga negara pada budaya keseluruhan Indonesia. (Koentjaraningrat, 1959: 139) menunjuk dengan jelas pada suatu soal di internasional, kebudayaan merupakan soal yang 
dilaksanakan karena berubahnya budaya di Indonesia. Yakni mengapa berubahnya budaya malah dihasilkannya keberagaman warga negara di Indonesia. Dengan dipaparkan secara menyeluruh dengan mendekati struktural, difusi, serta evolusi, dari sarjana Belanda dengan mendekati hal terbaru dari sarjana Amerika juga Inggris dengan dikaji percampuran pada perang dunia kedua. Jika antropologi sebelum Perang Dunia dilihat selaku kajian pada budaya Indonesia, hingga setelah perang selaku antropologi mengalami perkara kritis pencampuran, dikarenakan benturan budaya Eropa serta Amerika dengan warga di negara sisa jajahan.

Inti masalah akulturasi di Indonesia merupakan gimana mengisi nasionalisme dengan “ jiwa yang terbaru” (Koentjaraningrat, 1959: 173-174). Sehabis lebih dari separuh abad Indonesia merdeka, para antropolog butuh rasanya mengatakan sumbangan apa saja yang bisa diberikan bidang keilmuannya untuk akulturasi bangsanya dengan globalisasi. Mari kita memandang fragmen gimana penduduk Indonesia bersiasat di garis depan perjumpaan globalisasi dengan sumber energi alam serta manusia, kala apa saja dijadikan benda dagangan. Juga antropologi ambil bagian dalam gerakan pergantian budaya, partisipatif dalam isu pokok yang ditelaah sendiri. Hingga memiliki relevansi masalah sosial-kebudayaan bangsa. Antropologi bisa menyumbangkan penafsiran yang mendalam gimana konstruksi bukti diri budaya terbangun, maksudnya antropologi memiliki energi serta kapasitas buat mengawal supaya proses itu berjalan lebih balance ataupun memihak yang dilemahkan.

Dalam hidup, tiap hari pembelajaran antropologi nyatanya sangat memastikan posisi seorang dalam penduduk. Berkegiatan pembelajaran hingga peserta didik mendapat pengalaman dari proses belajar secara efektifitas pada perkembangan bersikap, ilmu pengetahuan, serta terampil dalam ikut menujukan pembelajaran yang sesuai (Abbas, 2021; Mutiani, 2019, 2021). Dasarnya pembelajaran antropologi menuju pada usaha perkembangan indidvidu yang terarah sasaran lebih substansi, kecil dengan kepedulian serta berempati kepada kehidupan individu dirinya daripada terarah kehidupan materi instan. Masa pengembangan ekonomi yang lagi dipacu, semacam di negara kita dikala ini, konflik internal dalam pembelajaran cenderung berjalan tidak balance. Adanya suatu penting buat melayani pasar, kuasa serta global cenderung ditunda, apalagi diabaikan perlunya pembelajaran antropologi buat dibimbing individu tumbuh terarah pada kehidupan lebih baik martabat utuh.

\section{Antropologi Sosial Serta Budaya}

(Koentjaraningrat, 1996) "Pengantar Antropologi” menggambarkan jika akademik, antropologi ialah ilmu mengenai individu yang biasanya dengan titik fokus kajian pada wujud 
raga, warga serta budaya manusia. Sebaliknya ialah ilmu menekuni manusia pada beragam warga suku bangsa, guna membangun warga suku bangsa sendiri (Agusyanto, 2007: 1.4). Perencanaan pembelajaran terlaksana lewat evaluasi terakhir pada pelaksanaan pembelajaran selaku tolak ukur peserta didik (Putra, 2020; Syaharuddin \& Mutiani, 2020). Pada antropologi sosial-budaya, manusia ialah komponen berarti untuk dirinya serta untuk alam lingkungan. Adanya hubungan bersama berkaitan serta saling berpengaruh antar manusia serta alam lingkungan. Manusia selaku makhluk bersosial wajib senantiasa hidup bersama. Individu hidup bersama-sama dengan kelompok pada persatuan sosial besar ataupun kecil. Dalam persatuan sosial inilah manusia hidup bersama mempunyai hubungan, kerja sama, serta tukar menukar pengetahuan buat menggapai tujuan hidupnya. Hasil kebudayaan manusia jadi landasan norma serta hasil buat mengendalikan juga menata kehidupan manusia dalam mengupayakan hingga menggapai pengembangan hidup beradab. (Klukhohn, 1953) membagi tujuh faktor budaya, seperti:

1. Metode TIK, melengkapi alat kehidupan manusia, yakni pakaian, rumah, alat rumah tangga, senjata, transportasi serta sebagainya.

2. Metode pencaharian hidup serta metode ekonomi, seperti bertani, berternak, metode menciptakan, metode penyaluran serta sebagainya.

3. Metode masyarakat, seperti kerabat, kelompok pemerintah, metode hukum serta metode pernikahan.

4. Metode bahasa, secara menulis ataupun berbicara.

5. Metode seni, bergerak, suara, rupa serta sebagainya.

6. Metode ilmu pengetahuan, juga

7. Metode kepercayaan (Burhan Bungin, 2006: 53)

Pembelajaran menyadarkan peserta didik mendapat keperluan pendidikan sesuai setiap peserta didik (Abbas, 2020; Ifa, 2014). Pada kelompok sosial terdapat bagian hasil serta norma yang sepakat bersama, manfaat didapat merupakan buat mengendalikan status serta peran manusia dalam susunan sosial. Nilai atau hasil ialah keyakinan yang didasarkan pada kode etik berlaku dalam warga. Hasil serta peraturan membagikan arahan pada manusia menimpa apa yang benar serta salah, baik serta kurang baik, membagi pedoman hidup buat masa saat ini serta hendak datang. Mengukur hasil ialah satuan interelasi pada bagian hasil yang terdapat pada sesuatu kelompok penting. Ikatan individu di berkehidupan sosial-budaya dipaparkan pada metode relasional. Hasil faktor berarti dalam budaya, sebab memastikan mengenai suatu itu boleh ataupun tidak boleh harus dicoba. 


\section{Komunikasi Serta Budaya}

Membicarakan mengenai komunikasi pasti pertama diasumsikan pada komunikasi itu memiliki hubungan dengan butuhnya individu serta dalam memenuhi keinginannya melakukan interaksi kepada individu lain. Keinginan memiliki hubungan bersosial ini untuk memenuhi timbal balik message yang fungsinya menjadi penyalur pemersatu individu secara berkelompok. Komunikasi ialah pelaksanaan dalam menyampaikan message individu dari komunikan menuju komunikator ataupun sebaliknya. Berlangsungnya ini pasti terlaksanakan, dari individu dikarenakan tingkah laku individu itu memiliki perilaku untuk berkomunikasi. Melangsungkan komunikasi ini terlibat pada komunikator, message, media, yang menerima, serta respon. Selain itu pelaksanaan ini selalu berubah serta terus terlaksana juga interaktif, yakni terjadinya ini antar yang menerima dan yang menyalurkan. Dalam melaksanakan berkomunikasi, langsung pada secara fisik juga sosial, sebab sifatnya yang interaktif hingga memungkinkan terjadinya komunikasi terisolasi. Pada hal fisik juga sosial yang selanjutnya menciptakan susunan komunikasi pada penduduk yang akan mengembang jadi kebudayaan. Kebudayaan ialah susunan dalam bangkitnya suatu keinginan dengan difinisnya selaku susunan pembelajaran, percaya, pengalaman, hasil, perilaku, makna, hakikat, keagamaan, time, peran, berhubungan tempat, pola keadaan alam, objek material, serta hal yang dipunyai kelompok besar dari generasinya lewat terjadi usaha manusia serta masyarakat (Mulyana, 1996: 18).

\section{Hubungan Komunikasi Serta Budaya}

Komunikasi juga kebudayaan tidak bisa terlepas satu dengan lainnya, sebab kebudayaan tidak saja menjadi penentu pada siapa dengan siapa, mengenai apa juga bagaimana individu pada menanggapi message. Arti terhadap mempunyai dalam message, serta situasi dalam pengiriman, peduli juga tafsiran message. Membentuk tingkah laku bisa terlaksana sebab sistem menuju dewasa, serta adanya komunikasi pada lingkungan (Abbas, 2017; Subiyakto, 2018). Budaya ialah awal komunikasi hingga menjadi beranekaragam latihan komunikasi pada pertumbuhan. Tiap warga hendak mempunyai metode komunikasi sendiri hingga dengan sendirinya melanjutkan kelangsungan hidup, tiap warga bisa membentuk kebudayaan (Depdikbud, 1995: 21). Bahasa hal utama dari komunikasi sekalian selaku pengawalan kenyataan untuk penduduk. Setelah itu komunikasi membentuk warga serta kebudayaan. Hingga bahasa secara tidak langsung ikut membentuknya budaya penduduk. 
Nilai kebaikan berupa moral ataupun perilaku di wariskan dari leluhur... (Putra, 2019). Dari sekian banyak manfaat budaya, para ahli antropologi yakin kalau bahasa-lah yang memegang peran utama dalam pertumbuhan kebudayaan manusia, sebab bahasa ialah hal utama buat meneruskan adat istiadat dari generasi satu ke generasi lain. Keahlian individu pada menumbuhkan tradisi kebudayaan, menghasilkan realita yang diungkapkan secara simbolik, serta diwariskan pada generasi seterusnya. Hubungan antar bahasa, kebudayaan, serta komunikasi, pada kehidupan sosial-budaya. Bahasa hidup dalam komunikasi buat menghasilkan kebudayaan, setelah itu budaya sendiri pada simpulannya hendak memastikan metode komunikasi serta mewujudkan bahasa semacam apa yang pantas (Kuswarno, 2008: 11). Hubungan antar komunikasi serta budaya secara konsep berkonsentrasi berhubungan lintas komunikasi verbal serta non verbal antara kelompok sosial pada warga. Hingga komunikasi antara kebudayaan biasanya menekuni bagian perihal, seperti:

1. Kode serta saluran meliputi sistem dialog, teori serta riset verbal, sistem komunikasi internasional, bahasa juga politik, budaya visual, serta analisis komunikasi dan budaya,

2. Praktek budaya, contoh retorika serta warga, politik-budaya, media serta peraturan negara, komunikasi antara individu, aplikasi mengkritik teori pada media massa, media gender serta ras,

3. Bagaimana cara riset meliput kualitas serta kuantitas, riset lapangan pada komunikasi, analisis isi, mengkritik retorika, serta meneliti filsafat.

Manusia pada konteks komunikasi antara kebudayaan ialah senantiasa berbicara dengan dengan sesamanya lewat expanse dan time. Keseluruhan konteks ini kerap kali ada dalam benak individu tapi butuh di mengerti kalau konteks itu campuran mengaitkan para partisipatif komunikasi yang mengisi expanse serta time komunikasi. Secara fenomenologis tidak dapat berdiri sendiri, dibutuhkan disiplin ilmu, sebab akibat sosial tidak-lah kenyataan yang berdiri sendiri tapi nampak ialah objek penuh dengan arti transendental.

\section{Simpulan}

Letak ilmu antropologi di wilayah Indonesia akan memberi tanggapan pada kehidupan dulu serta kehidupan sekarang maupun percampuran yang dirasakan warga negara pada budaya keseluruhan Indonesia. (Koentjaraningrat, 1959: 139) menunjuk dengan jelas pada suatu soal di internasional, kebudayaan merupakan soal yang dilaksanakan karena berubahnya budaya di Indonesia. Sehabis lebih dari separuh abad Indonesia merdeka, para antropolog butuh rasanya mengatakan sumbangan apa saja yang bisa diberikan bidang keilmuannya untuk akulturasi 
bangsanya dengan globalisasi. Juga antropologi ambil bagian dalam gerakan pergantian budaya, partisipatif dalam isu pokok yang ditelaah sendiri. Dalam hidup, tiap hari pembelajaran antropologi nyatanya sangat memastikan posisi seorang dalam penduduk. Berkegiatan pembelajaran hingga peserta didik mendapat pengalaman dari proses belajar secara efektifitas pada perkembangan bersikap, ilmu pengetahuan, serta terampil dalam ikut menujukan pembelajaran yang sesuai (Abbas, 2021; Mutiani, 2019, 2021). (Koentjaraningrat, 1996) "Pengantar Antropologi" menggambarkan jika akademik, antropologi ialah ilmu mengenai individu yang biasanya dengan titik fokus kajian pada wujud raga, warga serta budaya manusia. Sebaliknya ialah ilmu menekuni manusia pada beragam warga suku bangsa, guna membangun warga suku bangsa sendiri (Agusyanto, 2007: 1.4). Pada kelompok sosial terdapat bagian hasil serta norma yang sepakat bersama, manfaat didapat merupakan buat mengendalikan status serta peran manusia dalam susunan sosial. Nilai atau hasil ialah keyakinan dasar dalam kode etik berlaku pada penduduk. Melangsungkan komunikasi ini terlibat pada komunikator, message, media, yang menerima, serta respon. Selain itu pelaksanaan ini selalu berubah serta terus terlaksana juga interaktif, yakni terjadinya ini antar yang menerima dan yang menyalurkan. Komunikasi juga kebudayaan tidak bisa terlepas satu dengan lainnya, sebab kebudayaan tidak saja menjadi penentu pada siapa dengan siapa, mengenai apa juga bagaimana individu pada menanggapi message. Budaya ialah awal komunikasi hingga menjadi beranekaragam latihan komunikasi pada pertumbuhan. Dari sekian banyak manfaat budaya, para ahli antropologi yakin kalau bahasa-lah yang memegang peran utama dalam pertumbuhan kebudayaan manusia, sebab bahasa ialah hal utama buat meneruskan adat istiadat dari generasi satu ke generasi lain. Keahlian individu pada menumbuhkan tradisi kebudayaan, menghasilkan kenyataan yang diungkapkan secara simbolik, serta diwariskan pada generasi penerusnya. Keseluruhan konteks ini kerap kali ada dalam benak individu tapi butuh di mengerti kalau konteks itu campuran mengaitkan para partisipatif komunikasi yang mengisi expanse serta time komunikasi. Antropologi secara fenomenologis tidak dapat berdiri sendiri, dibutuhkan disiplin ilmu, sebab akibat sosial tidak-lah kenyataan yang berdiri sendiri tapi nampak ialah objek penuh dengan arti transendental.

\section{Referensi}

Abbas, E. W. (2019). Building Nation Character Through Education: Proceeding International Seminar on Character Education. 
Amelia, R., Putro, H. P. N., \& Permatasari, M. A. (2020). The Role of Caregivers as a Social Attitude Developer in The Children's Social Homes Budi Mulia Banjarbaru. The Kalimantan Social Studies Journal, 2(1), 56-61.

Ilmiyannor, M., \& Mi'rajiatinnor, D. (2021, February). Strengthening Environmental Care Attitudes Through Social Wisdom-Based Social Studies Learning. In The 2nd International Conference on Social Sciences Education (ICSSE 2020) (pp. 65-69). Atlantis Press.

Indriyani, I. E., Syaharuddin, S., \& Jumriani, J. (2021). Social Interaction Contents on Social Studies Learning to Improve Social Skills. The Innovation of Social Studies Journal, 2(2), 93102.

Laksono, P. M. (2013). Kontekstualisasi (Pendidikan) Antropologi Indonesia. Komunitas: International Journal of Indonesian Society and Culture, 5(1).

Muchtar, K., Koswara, I., \& Setiaman, A. (2016). Komunikasi antar budaya dalam perspektif antropologi. Jurnal Manajemen Komunikasi, 1(1).

Prayitno, E., Kurniawati, D., \& Arvianto, I. R. (2018, October). Pemanfaatan Teknologi Informasi dan Komunikasi (TIK) Untuk Meningkatkan Kualitas Pembelajaran. In Seminar Nasional Call For Paper \& Pengabdian masyarakat (Vol. 1, No. 01).

Putra, M. A. H., Mutiani, M., Jumriani, J., Ramadhan, S., \& Rahmatina, R. (2020). Utilization Learning Management System (LMS) of Ruang Guru for Education Teachers in Banjarmasin. The Kalimantan Social Studies Journal, 2(1), 31-38.

Rahayu, R., Abbas, E. W., \& Jumriani, J. (2021). Social Studies Lesson Planning for Children with Intellectual Disabilities in the Pembina State Special School of South Kalimantan Province. The Kalimantan Social Studies Journal, 2(2), 160-169.

Susanto, H. (2020). PEDAGOGI SEJARAH, NASIONALISME DAN KARAKTER BANGSA. Preprint: EdArxiv

Susanto, H., Irmawati, I., Akmal, H., \& Abbas, E. W. (2021). Media Film Dokumenter Masuknya Islam Ke Nusantara dan Pengaruhnya Terhadap Keterampilan Berpikir Kritis Siswa. HISTORIA: Jurnal Program Studi Pendidikan Sejarah, 9(1). 